\title{
IMMEDIATE POST-WORLD WAR I HUNGARY THROUGH THE EYES OF AN AMERICAN
}

\author{
ZOLTÁN PETERECZ \\ Eszterházy Károly University, Eger \\ Institute of English and American Studies \\ zpeterecz@yahoo.com
}

\begin{abstract}
The one hundredth anniversary of the end of World War I and the subsequent peace negotiations will inevitably become a historical focal point. Accordingly, this article will deal with American involvement in Europe, but especially in Hungarian affairs with regards to the private realm rather than the official spectrum. American participation always bordered official yet unofficial conduct, which is even truer for the successor countries in Central Europe. A few Americans visited Hungary during the Peace Conference in various capacities. Although their official work has been to a large degree uncovered by historians, their private work still remains elusive. Hence, the diary of such an American officer will shed light on various interesting angles of American thinking of the era and the relationship between American representatives and various Hungarians of the day. The article will introduce Charles Moorfield Storey's journal, a significant part of which was written while he was in Hungary in the first few weeks of 1919. Storey was a member of the famous Coolidge Mission, whose headquarters was in Vienna. From here Americans set out to visit and gather information on the various countries in their purview, Hungary among them. Based upon the diary entries, one can learn about daily work of the Americans at the Paris Peace Conference, the Coolidge Mission, and Storey's experience in Hungary shortly after the conclusion of the war.
\end{abstract}

Keywords: Paris Peace Conference, United States, Hungary, Transylvania, 1919, Charles Moorfield Storey

In early 1919, in the immediate postwar surroundings, just after the Peace Conference had started, the situation in Hungary was fluid. At the end of the war, on October 31, a revolution swept the country and the aristocrat but socially radical Mihály Károlyi became president. The newly claimed republic had an unstable new government, and Károlyi put all his hope into the outcome of the future peace treaty supposedly based upon Wilsonian principles of national self-determination. As Károlyi famously declared, Hungary had three options to choose from: "We have one principle: Wilson, Wilson, and for the third time also Wilson." Although Hungary had to expect some kind of punishment, and the full throttle of nationalistic upsurge in the successor states did not bode well for Hungary either, the prestige and declared peace aims of Wilson's kept Hungarian hopes alive as 
to the outcome of any treaty. Little did the current Hungarian political leadership know that the United States was not really interested in the Central European region, and Wilson's main hope, behind his shining rhetoric, was the League of Nations, for which, as subsequent events proved, he was willing to give up other principles that were to hurt Hungary to a great degree.

The American Peace Delegation, exactly in order to learn about the often anomalous-looking Central European region, sent the Coolidge Mission to Vienna on the first day of 1919. This mission was responsible for gathering as much information as possible at its headquarters in Vienna and in the countries in the region: Hungary, Romania, the Kingdom of Serbs, Slovenes, and Croats, and Poland. The motley group of Coolidge's mission consisted of military officers, university and college professors, and lawyers. It was the mission's task to gather valuable information concerning the present position and outlook of the countries mentioned and relay useful data to Paris to help the American Peace Delegation in making decisions. Archibald Coolidge sent the various members to the countries and tried to keep the flow of information to Paris at a sustainable and satisfactory pace. ${ }^{2}$

Hungary was one of the most important countries among the aforementioned places, and Coolidge deemed it important to travel there in person. He wanted to meet Károlyi and gain a firsthand impression about the situation in Hungary. He took Charles M. Storey with him, a young Boston lawyer. Storey, according to the trend of the day, kept a diary in which he put down the main events of a given day and his impressions concerning those events and the characters involved. Since he spent about six weeks in Hungary, his diary entries starting from the end of World War I until he arrived back in Paris in early March is an invaluable source as to how members of the American mission thought about the postwar world and Hungary's place in it, what the American attitude was concerning Europe, Central Europe in general, and Hungarians in particular.

\section{The Diary as History}

The diary as a form of and mirror on history has been around for centuries, but the first detailed diary entries came into being in the renaissance; this era produced an earlier unknown measure of self-consciousness and, in the wake of it, a larger need for self-reflection. ${ }^{3}$ The almost universal practice of noting observations in a diary, however, really grew in popularity in the mid-nineteenth century. Most typically, persons belonging to the upper classes in general grabbed their pens, but diplomats and politicians in particular were active in this field. Today, this form of preserving the present seems to be on the wane, largely due to the digital and globalized world, where the visual image is taking its place. The diary entry is a living imprint of history, since those persons scribbling down events into 
their diaries reflect fresh experience and observation, and they do it right after the event takes place, so the typically distorting feature of many years and distant memory do not play a role in being historically correct. On the other hand, the diary entry can also be seen as a form of literature, even if the notes sometimes in short form are not representatives of fine literature. That is why it has an "unsure status," because the diary is "an uncertain genre uneasily balanced between literary and historical writing, between spontaneity of reportage and the reflectiveness of the crafted text, between selfhood and events, between subjectivity and objectivity, between the private and the public." ${ }^{4}$ Obviously, one always has to be on guard when faced with a diary entry, because, if nothing else, the unavoidable subjectivity will play a part. Still, these entries usually reflect history well. This does not mean that we should look at diaries as refutable historical artifacts, since these texts are personal "images" only. ${ }^{5}$ Colouring, magnifying, distorting, and errors are all parts of it, but that also holds true for professional history writing. Despite examples to the contrary, in most cases the author of a diary entry does not purposefully distort the story he or she writes down. The author's primary goal is to preserve the present and not to lie about history. ${ }^{6}$ The author wishes to read the entries, to be able to reproduce events and feelings ten, twenty, thirty, or more years later, irrespective of its nature - family, politics, or war. There have been diary writing persons who knew that the public would read what they wrote, so they wrote their diaries through this prism. ${ }^{7}$ In the case of Charles Moorfield Storey this cannot be detected.

At the same time, depending on time and place, the level of "freedom" of the diary entries may differ. If someone lives in a society and jots down events when they do not need to worry about the material getting into the wrong hands, the opinion will be in a more open channel, in a more "honest" style. On the contrary, in the atmosphere of an oppressive regime, a diary person will choose to circumvent wording and style, even perhaps a code, driven by the fear of what might happen to them if the authorities find the entries, read them, and, as a consequence, punish the author and /or their family. As such Charles M. Storey could write as freely as he wished, even if some of his entries were put down in foreign countries - he did not need to worry about losing them or being punished for their contents. Naturally, only looking back a hundred years later can we appreciate the historical significance of some of the entries in the diaries.

\section{Charles Moorfield Storey}

Charles M. Storey came from a rather prominent family. His father, Moorfield Storey (1845-1929), was a well-known lawyer in Boston, Massachusetts, with a long practice, various titles in associations, and was a liberal person in his po- 
litical and legal outlook. ${ }^{8}$ His son, Charles Moorfield Storey (1889-1980), was a Harvard graduate, who, after getting his law degree, worked in the Justice Department until the end of World War I. After the war he became a member of a law firm where he stayed for the remainder of his life. He held various posts as members, presidents, and trustees in different organizations, of which being Harvard overseer for five years made him the proudest. ${ }^{9}$

It is not absolutely clear why Storey started to take notes of his daily adventures and chores in November 1918. Seemingly he had not done this activity earlier, so in all likelihood he must have thought that the radical events surrounding him called for a personal imprint to have for either later personal use or for historical preservation. Irrespective of this, he used the safe haven and personal structure of the diary to record events as he saw them. Depending on the heavy schedule he was subjected to at times, certain entries were put down one or two days later while still fresh in memory. Storey's diary can be divided into two sections. The first half deals with his work in Paris in the last six weeks of 1918, whereas the second half tells his experiences as a member of the Coolidge Mission in the first two months of 1919, the larger part of which was spent in Hungary - f orty days from mid-January. Both halves are interesting, sometimes fascinating, and they are worthy of being introduced for the first time to a wider audience.

Compared to another detailed diary written by another member of the Coolidge mission, it can be established that Storey was in many ways more open-minded and less filled with prejudice than many of his fellow Americans working in Paris and in the various missions, a trait that he probably inherited from his father. For example, he often came across people of Jewish extraction but it is hard to detect the widely spread anti-Semitism of the day in his words. He hints at a slight distaste for Jews, especially in relation to Davison, his assistant on his journey to Transylvania, but, for instance, Nicholas Roosevelt's rant-like spurts of anti-Semitism make Storey's criticism an act of love and respect toward Jews. ${ }^{10}$

\section{Charles Moorfield Storey in Paris}

As to his work in Paris as a member of the American Peace Delegation, Storey's entries are interesting and shed some light on how intelligence work was tackled by the Americans immediately after the war had finished. The diary entries start on November 14, 1918, when he arrived in Paris from Switzerland. ${ }^{11}$ In Paris he basically met the Who's Who of the American Peace Delegation - Colonel House, Walter Lippmann, Joe Grew, Gordon Auchincloss, Leland Harrison, Allen Dulles, Isiah Bowman, General Tasker H. Bliss, William Bullitt, Archibald Coolidge, and others. After ten days of fog and seeming purposelessness, on November 24, 1918, Grew offered Storey the job of Executive head of the Bureau 
of Political Intelligence. This highly pleased Storey, since "there was scarcely anything I would have wanted more." 12 This job basically entailed collecting information of all sorts, reading countless appeals and memoranda, and preparing all this data into an easily comprehendible form for use of the members of the American Peace Delegation and other Americans working outside Paris all across Europe. His group brought out the The Official Bulletin of the American Commission to Negotiate Peace, a news outlet concerning the various ongoing issues, appearing daily, sometimes twice a day, although it existed only for a short period of time. Storey felt he was suitable for such work and looked forward to carrying it out to the best of his abilities.

From Storey's diary entries not only can one read about some of the daily chores and problems arising from that particular job, but some keen observations also emerge regarding the postwar European scene and the United States' position in it. One of his sharpest observations about continental Europe, aside from France, was what was expected and hoped from the United States. In the postwar turmoil and chaos, as Storey put it, all these old and newly formed, or being formed countries that were in the process of being formed, looked to America "as a composite saviour, guardian angel, boundary commission, and food supply." 13 The seeming contradiction in his mind was that while Europeans in general expected and believed that the United States possessed impartiality, which he agreed they carried with them, Europeans also attributed to America "clairvoyance in things political, which we lack to a degree that is as incredible as it is alarming." 14

Concerning American policy, he wrote in his dairy about President Woodrow Wilson and his peace proposals, the famous 14 Points, the following: "I have felt that we have been drifting, waiting for the President to come and put concreteness to his abstract propositions." 15 This was unveiled criticism as to how Storey saw Wilson and his plans for the postwar world. He found in the President an idealist when realism was in demand. He was convinced that Wilson came without proper preparation, "a Sir Galahad from the West with a wooden sword to carve the casques of some of the hardest-headed individuals in Europe today." ${ }^{16}$ His views were not extraordinary. They were largely shared by many of his fellow Americans participating in the Peace Conference at that time. ${ }^{17}$ And, in Storey's view, this permeated the whole American approach to the Peace Conference, which led to the experienced Europeans taking advantage. "They know we have no plan," noted Storey, "and that if we are given the form of that for which we have fought, we will go home like children, happy in a toy, and let them have the substance."18

He also complained that gathering information was difficult without having the right people across Europe at such crucial places from which reliable information was highly needed. For this he accused the mechanism in place which worked cumbersomely, partly owing to the State Department, Herbert Hoover's Food Agency, and the aforementioned lack of agents in various European cities. 
Also, he was principally dissatisfied with the seeming heedlessness, lack of organization, and his unstable role in gathering information: "the constant shifting is beginning to irritate", he wrote. "It seems quite extraordinary that there should be such an infinite purposelessness, and such a constant vacillation in so many individuals." 19 This grew especially troublesome for him after the arrival of The Inquiry in Paris, which study group basically took over his job, and Storey's organization was going to be integrated into The Inquiry. This is important since it makes it much more obvious why he would join the Coolidge mission in a few weeks' time to do exactly that kind of work whose lack he criticized so much. According to his diary, it was on December 11, 1918, that he first talked with Archibald Coolidge about sending a mission deep in Europe, and he countered Coolidge's plan as to the headquarters of that future mission. While Coolidge proposed the Balkans as the nerve center of any mission, Storey advocated Vienna for headquarters and smaller centers in the neighbouring countries, which became the final plan. ${ }^{20}$ Before Christmas it was officially decided that the Coolidge Mission was to go to Vienna and carry out information gathering on spot and in neighbouring countries. The mission was to be strictly in observing capacity and was not to hint that it carried diplomatic responsibilities, which Storey interpreted as giving the mission the "mere impossibility of accomplishing anything." 21

\section{Charles Moorfield Storey in Hungary}

Finally, on December 27, the first group of the Coolidge Mission (eleven people) left for Vienna, followed by the somewhat larger second group — including Storey - on January 3, and arrived in Vienna a week later. In Vienna, it was soon sorted out who was going to which country, and Coolidge decided that he was personally visiting Budapest because he wanted to meet Mihály Károlyi and gain a firsthand impression of the local situation. He took with him his secretary, Parker, Major Lawrence Martin, Philip L. Goodwin, a courier, Sgt. Davison, the stenographer, and Storey. Coolidge was to stay only four days after which time Storey and Davison were to remain and carry on the task of gathering as much information as possible from various places. Storey started to prepare for the journey by studying books on Hungarian history, and with this knowledge about an earlier unknown country he and the company - after a fifteen-hour train ride — arrived in Budapest on the morning of January 15.

Their time in Hungary was busy as expected. After a crowd greeted them at the railway station, the program was meeting after meeting with various shades of Hungarian society. Naturally, Károlyi and his government received larger attention, as the de facto leaders of the country. The very first day of their stay in Budapest the Coolidge Mission had a talk with President Károlyi, the new Prime 
minister Dénes Berinkey, and other members of the cabinet such as Oszkár Jászi, Barna Buza, and others. In the evening there was a reception hosted by Károlyi to the American delegation. Károlyi for some reason chose Storey and spoke to him for a long time in private, and the American was clearly enchanted by Károlyi: "He struck me as being sincere, honest, a man prone to thinking better of the world that it deserved, an idealist... an extremely human person, capable of exciting a blind affection, based as much on his weakness as on his strength." ${ }^{\prime 2}$ The next day the notorieties kept coming in the persons of Pál Teleki, Ernö Garami, Sándor Festetics, which was followed by lunch at Sándor Podmaniczky, while the evening Károlyi gave another reception for the American mission. Coolidge found the reception given to them quite overwhelming. A few days later in a letter to his mother, he chronicled that "it was a hectic and wonderful experience for me. I am not exactly used to sitting proudly and being harangued by ten bankers and financiers, having to speak from a hotel balcony to a cheering crowd of students, having a lunch given in my honour by a President (and arriving half an hour late, owing to aforesaid students), being called upon by an archduke and occupying his long-vacant box at the opera and having to stand and bow graciously amid the plaudits of the audience - all this in the course of one short day." ${ }^{23}$

The following days passed in the same vein: meetings with leading personalities and various delegations like the Hungarian Integrity League, German Hungarian National Council - both with petitions - , the League of Americans in Hungary, and a Szekler delegation. The latter was accompanied by a large crowd outside the building and they presented Storey for the first time with the Szekler Anthem - a performance that was to be repeated quite a few times during his stay in Hungary, especially in Transylvania. He soon formed the opinion that he based upon his interactions with the various shades of Hungarian society: "if Karolyi is forced out, I cannot yet see any person or group capable of succeeding him even momentarily. Of the persons we have talked to, the Socialists are much the most advanced, and intelligent. They seem to have ideas. The others refrain themselves to emotions. ${ }^{24}$ This was also unveiled criticism of the aristocrats that he had talked to, and who struck him as unconstructive elements concerning the future. As for Coolidge, he informed Paris about his impression based upon the four days spent in Hungary. He underscored that despite his best efforts to emphasize that his mission had no diplomatic nature, "I have not been able to prevent what seems to be a general feeling that this is the first chance that the Hungarians have had to put their views before the Allied powers and especially before America, as they look primarily to America for their salvation." ${ }^{25}$

After Coolidge left for Vienna, Storey remained the American leader in Hungary, and the next days passed in a whirl of work consisting of meetings, lunches, teas, dinners, and putting together dispatches to be sent to Vienna. Storey found the schedule and the content of this daily rhythm of information flow "deaden- 
ing." He felt that "the mind loses its spring, and its receptivity." ${ }^{26}$ In addition to the mental stress, Storey's wife was at home pregnant with their third child. The two-day stint of Wilson's propaganda tsar, George Creel, in Budapest obviously did not make Storey's life any easier. Since he was so overburdened with facts, opinions, and rumours, he thought that he would put down the most essential events of the given day in his diary and would not write down his personal impressions concerning Hungary and Hungarians. Despite this approach, luckily he noted various hints and impressions regarding the surrounding place and people, even if he indeed resented committing deeply personal opinion to his diary pages. For instance, after a talk with a certain Székely from the Ministry of Commerce, he opinioned, if "the aristocrats had half as much brains and half as many ideas as Székely, they could go far, for they have what the persons running the Government at present lack - training and experience."27

However, Storey committed perhaps his most personal views to a private letter he wrote to Allen Dulles, who was member of the American Peace Delegation in Paris. The most interesting passages are those that deal with Károlyi and the situation of Hungary in the postwar world. Speaking of Károlyi, he made the following observation: "He is an idealist, something of a dreamer, scrupulously honest, considered by some a poor judge of men and subject to the influence of stronger characters. Personally he is extremely attractive, a good talker and has made a deep impression on all of us. There is no doubt as to the depth and sincerity of his conviction and to his force. To my mind he is an extremely forceful personality, and has displayed considerable political instinct." ${ }^{28}$ His words in many ways echo some of the diary entries, but are put in a more coherent and sophisticated form. As to the government as a whole he characterized it as an inexperienced and motley crew as far as politics and sincerity went, but he also admitted that this government faced "an impossible situation, and I cannot see how any other course can be pursued with greater promise of success under the present circumstances. ${ }^{29}$ In his opinion it was a mistake not to send a clear sign from Paris so that the Hungarian government, which wanted to follow a pro-Entente policy, could accommodate itself accordingly, and, after all, it was the Károlyi government that was "of progress and of order" and deserved support. ${ }^{30} \mathrm{He}$ also wrote that the Allies had broken the armistice "right and left," and advocated that "until boundaries are settled, Hungary must be allowed civil control in occupied territories, as specifically agreed in the armistice, for the purpose of raising money and holding provisional elections." ${ }^{31}$ Storey also reflected on the general mood of Hungarians and concluded that "the apathy of the Hungarians" was due to immediate postwar sentiment, and brought on "by defeat, by hopelessness for the future, and to a certain extent by the promises of the Government that if the people keep quiet, all will be rendered to them by a just and beneficent distribution." ${ }^{32}$ He somewhat prophetically added, "How long it will last God knows." 
In tandem with many other American observers of Hungary in the postwar years, Storey shared his belief that "Hungary is at the cross-ways between Western civilization and Balkanization. She wants to become the Eastern bulwark of the West, but if her offer is not accepted, fear may throw her into the hands of the Slavs... or Germany." 34

In the evening of February 10, Storey, Davison, and Emil Zerkowitz, the latter being their official guide from the Hungarian government, left for Arad to commence a 10-day journey across Transylvania to learn the situation there personally. This area was crucial, since Transylvania had come under Romanian military rule but it contained huge Hungarian and, to a lesser degree, Saxon minorities sometimes in compact ethnic blocks. The itinerary included the following places: from Arad to Kolozsvár via Nagyszeben, Brassó, Sepsiszentgyörgy, Csíkszereda, and finally Marosvásárhely A certain Sándor Rákóczi-Filep, a lawyer from Szatmár and member of the Nagyszeben Council, was their guide in Transylvania, where Zerkowitz was not allowed to escort them.

The Romanian military tried to oppose Storey in his visit and what he wanted to do, but after a clash of wills, Storey came up on top, in which his nationality helped him enormously. At Nagyszeben he met Julius Maniu, president of the civil government of Transylvania, where at the reception given by the Romanian, Storey found himself in the uncomfortable situation of having to give a toast, but wanted to preserve his impartiality at all cost. Since the day fell on February 12, he managed to escape a possibly unpleasant situation by evoking Lincoln as it was the president's birthday, and somewhat hiding behind those ideals he did not have to look partial to either side. He also secured from Maniu a document ensuring that those Storey was going to speak to feared no consequences regarding their honesty.

In Transylvania Storey was unavoidably dealing with the territorial question in his mind. He made a very strong effort to preserve his unbiased outlook on the problem and tried to approach it with pure pragmatic thinking. His own solution to the intricate situation was to settle the dispute "by dividing the country on an east and west line drawn north of the River Maros, nearly up to Maros Vasarhely, and then south easterly to the boundary east of Brasso." ${ }^{35}$ Transylvania as a physical landscape left Storey with the following impression: "Transylvania is a large generous country, restful to my eyes, on account of its distances, but cheerless, bare, and terribly forbidding in some aspects." ${ }^{\prime 36}$ The Szekler people struck him as crude but honest folks: "I must say that the Szeklers made us feel very much at home. To my mind they resembled our New Englanders, with a certain simplicity, sturdiness, and an independence amounting to obstinacy in many cases." ${ }^{37}$ But from a political aspect the verdict was different, especially after conducting a handful of interviews in Kolozsvár: "In the first place all these people were so irreconcilable, so pigheaded, so narrow-minded. Secondly they were utterly 
out of joint with the new tunes; and were being buoyed up with hopes for the return of the old royal order. Lastly they were not thinking; which was the saddest of all. The most that could be said was that they were brooding over present wrongs, and idealizing a dull and long moribund past." ${ }^{38}$ The constant interviews with Hungarians, Saxons, Romanians, and Jews, Storey found exhausting, and on more than one occasion there were gatherings of Hungarians outside his place singing the inescapably Szekler anthem - that put extra burden on Storey as an American trying to preserve his absolute impartiality in a multi-ethnic place. The cultural aspect also played a part in his experience there, pertaining from food to artifacts. Since he could not pursue his avid stamp collecting in Transylvania, instead he purchased a lot of embroidery, some clothing, and an old Transylvanian rug that reminded him of Navajo blankets as far as design went.

Interestingly, Storey's Transylvanian trip left a bitter taste both in the Hungarians' and in the Romanians' mouths. Károlyi complained to Nicholas Roosevelt, the person from the Coolidge Mission who replaced Storey in March, about Storey, for the latter being too close to the conservatives and spending too much time with them. Roosevelt characterized Storey as "breezy, changeable, and lacking in the ability to run things," and who "showed a complete lack of understanding of the way a European looks at things." ${ }^{39}$ More seriously, the Romanians accused Storey of being a Hungarian spy, because he wanted to bring Hungarians with him to military occupied territory (which the Romanians naturally did not allow) and kept asking about the strength and distribution of Romanian troops. Also, as far as Romanian taste was concerned, Storey interviewed a disproportionally large number of Szeklers.

Storey returned to Budapest on February 21, whence he sent dispatches to Vienna and Paris, and two days later received orders from Coolidge to return to Paris via Vienna. On his last day in Hungary he managed a "best of" farewell tour concerning the defining political personalities of Hungary. First he had a call by Albert Apponyi, and he made a farewell visit to Károlyi for a lunch at the Palace, while later he also met Pál Teleki. He warned the Hungarian president that Hungary should not have high expectations concerning the Peace Conference, to which Károlyi allegedly responded, that were Hungary to be dismembered, Hungary would endeavour to seek a union with Germany and German Austria. ${ }^{40}$

His last day in Budapest gave him a sense of summarizing his feelings, which were influenced by the ongoing stress of the past few months: "the power of receiving impressions had been completely dulled. I was fed up, and frankly worn out." ${ }^{41}$ His approaching trip to Paris filled him with foreboding. "To try to convince any of our people that certain things ought to be done; to bring them up to the point of taking action; to concentrate upon the things that were worth while talking about; to help an enemy state with no power to help itself; and finally, after convincing the Americans that some specific things ought to be done, to get the rest to agree to them seemed almost impossible." ${ }^{42}$ 


\section{Conclusion}

Naturally it is worth asking what may be missing from the diary. What was it that perhaps Storey left out for some reason? And if he did, why did he do it? For instance, without suggesting that he intentionally distorted his own diary entries, he failed to mention during his Transylvanian tour that he was after Romanian troop movements. This must have not only surprised and angered the Romanians, but naturally bred suspicion towards Storey, and the overreacted opinion was that he was the paid agents of the Hungarian government. ${ }^{43}$ Károlyi also criticized Storey after his departure to another American. In this case the charge was too much conservativism on Storey's side, the alleged proof of which was that he had met Albert Apponyi and suggested that Apponyi would be a wise choice for the peace conference. ${ }^{44}$ It is a further point whether Storey was a good observer. To be sure, such a question cannot be answered with total certainty, but based upon available documents, his observations regarding the position of the United States, Hungary, and the Hungarians should be taken into account. In an alien environment where everybody wanted to impress him favourably, another issue is whether he could stay impartial to the situation or became biased. The weeks spent in Hungary and the unavoidable Hungarian propaganda must have had some effect on him, and this might have gained further momentum during his stay in Transylvania. But to say that he was friendly to Hungary would be an overstatement. What is closer to the truth is that he felt that the already tangible and expected punishment for Hungary was excessive. The most important question is, however, how well Storey carried out his task while in Hungary and Transylvania. His first and foremost job was to observe and inform: to size up the situation and send reports to Coolidge in Vienna and to the American Peace Delegation in Paris, so that his observations could have a practical effect. As far as Storey was concerned, he did his best: his statements were not overboard, no bias could be detected in them, and even if he made steps subject to criticism, he was not alone among the Americans working in the various missions in Central and Eastern Europe.

What can we learn from Charles Storey's diary? First of all, it has to be emphasized that the material is unique. Among the Americans working in Paris in 1918-1919, a relatively large number led either a diary or put their memory into a book form later on. However, very few of these Americans visited Hungary at this time, let alone Transylvania. Therefore, the one and a half months that Storey spent in postwar Hungary in January and February of 1919, and the diary notes accompanying that time frame give us an extra dose of information about Hungarian affairs. One can learn about the events and personalities through the eyes of an American. It is further proven that the Americans approached the questions of the region in an impartial way, but it was a foregone conclusion that Hungary was to face punishment for the war. The really crucial question was rather how strict such a penalty was going to be, since the wishes of the newly formed 
countries to the north, west, and south, and Romania to the east also had to be taken into account. Storey may have had an overall positive impression about his experiences in Hungary, but his reports apparently did not carry much weight, and the American delegation in Paris was concentrating on more pressing issues, and Hungarian ethnic blocs possibly coming under the rule of a new country was not among those. Storey's descriptions of his talks with Károlyi and his tour in Transylvania still provide an immensely interesting and important historical imprint, which sheds further nuances on the course of the first two months of 1919 in Hungary.

\section{References}

Chase, Theodore, „Charles Moorfield Storey,” Proceedings of the Massachusetts Historical Society, Third Series, Vol. 92 (1980).

Coolidge, Harold Jefferson and Lord, Robert Howard, Archibald Cary Coolidge: Life and Letters. Boston and New York: Houghton Mifflin. 1932.

Gyáni, Gábor, „A napló mint társadalomtörténeti forrás”, [The Diary as Sociological Source] Szabolcs-szatmár-beregi levéltári évkönyv, 1997, vol. 12.

Jeremiah Smith Academy Archives, Class of 1945 Library, Phillips Exeter Academy, New Hampshire, United States.

Kennan, George F., The Kennan Diaries, Frank Costigliola ed., New York: W. W. Norton, 2014.

Pritz, Pál, „Napló és történelem”, [Diary and History] Múltunk, 2017, vol. 62, no. 1.

Ransel, David L., "The Diary of a Merchant: Insights into Eighteenth-Century Plebeian Life," The Russian Review, Vol. 63, No. 4 (Oct., 2004).

Roosevelt, Nicholas, A History of a Few Weeks (unpublished manuscript), Box 18, Nicholas Roosevelt Papers, Syracuse University Libraries, United States.

Storey, Charles M. 1919, Box 53 Folder 19, Allen W. Dulles Papers; Pubic Policy Papers, Department of Rare Books and Special Collections, Princeton University Library, United States.

Wambaugh, Eugene, "Moorfield Storey (1845-1929)," Proceedings of the American Academy of Arts and Sciences, Vol. 71, No. 10 (Mar., 1937).

Charles Moorfield Storey Journal, 1918-1919, Massachusetts Historical Society, Boston, United States.

Pesti Hirlap, December 31, 1918.

\section{Notes}

1 Mihály Károlyi’s speech, Pesti Hirlap, December 31, 1918.

2 For the history of the Coolidge Mission see Harold Jefferson Coolidge and Robert Howard Lord, Archibald Cary Coolidge: Life and Letters, (Boston and New York: Houghton Mifflin, 1932), 192-216.

3 David L. Ransel, "The Diary of a Merchant: Insights into Eighteenth-Century Plebeian Life," The Russian Review, Vol. 63, No. 4 (Oct., 2004), 596.

4 Rachael Langford and Russell West, eds., Marginal Voices, Marginal Forms: Diaries in European Literature and History (Amsterdam, 1999), 8. 
5 Gábor Gyáni, „A napló mint társadalomtörténeti forrás”, [The Diary as Sociological Source] Szabolcs-szatmár-beregi levéltári évkönyv, 1997, vol. 12, 25.

6 Pál Pritz, „Napló és történelem”, [Diary and History] Múltunk, 2017, vol. 62, no. 1., 4-6

7 One of the best examples is George F. Kennan. The Kennan Diaries, Frank Costigliola ed., (New York: W. W. Norton, 2014).

8 Eugene Wambaugh, "Moorfield Storey (1845-1929)," Proceedings of the American Academy of Arts and Sciences, Vol. 71, No. 10 (Mar., 1937), 552-556.

9 Theodore Chase, „Charles Moorfield Storey,” Proceedings of the Massachusetts Historical Society, Third Series, Vol. 92 (1980), 151-156.

10 See Nicholas Roosevelt, A History of a Few Weeks (unpublished manuscript), Box 18, Nicholas Roosevelt Papers, Syracuse University Libraries, United States.

11 He was a member of the Garrett Mission, which dealt with American and German prisoners of war at Berne, September 24-November 11, 1918. John W. Garrett was United States Minister to the Netherlands.

12 Diary entry of November 24, 1918, Charles Moorfield Storey Journal, 1918-1919, Massachusetts Historical Society, Boston, United States, hereafter cited as C. M. Storey Journal.

13 Diary entry, November 26, 1918, C. M. Storey Journal.

14 Diary entry, November 26, 1918, C. M. Storey Journal.

15 Diary entry, December 14, 1918, C. M. Storey Journal.

16 Diary entry, December 14, 1918, C. M. Storey Journal.

17 For example, see personal expression of their views such as Nicholas Roosevelt or Jeremiah Smith, Jr.: Nicholas Roosevelt, A History of a Few Weeks, (unpublished manuscript), Box 18, Nicholas Roosevelt Papers, Syracuse University Libraries, USA; Jeremiah Smith, Jr.'s account to his father about the Paris Peace Treaty, July 1921, Jeremiah Smith Academy Archives, Class of 1945 Library, Phillips Exeter Academy, New Hampshire, USA.

18 Diary entry, December 14, 1918, C. M. Storey Journal.

19 Diary entry, December 16, 1918, C. M. Storey Journal.

20 Diary entry, December 11, 1918, C. M. Storey Journal.

21 Diary entry, December 20, 1918, C. M. Storey Journal.

22 Diary entry, January 15, 1919, C. M. Storey Journal.

23 Coolidge to his mother, January 22, 1919, quoted in Coolidge and Lord, Archibald Cary Coolidge, 210.

24 Dairy entry, January 17, 1919, C. M. Storey Journal.

25 Coolidge to the American Mission in Paris, January 19, 1919, quoted in Coolidge and Lord, Archibald Cary Coolidge, 211.

26 Diary entry, January 22, 1919, C. M. Storey Journal.

27 Diary entry, February 5, 1919, C. M. Storey Journal.

28 Storey to Dulles, February 3, 1919, Storey, Charles M. 1919, Box 53 Folder 19, Allen W. Dulles Papers; Pubic Policy Papers, Department of Rare Books and Special Collections, Princeton University Library.

29 Ibid.

30 Ibid.

31 Ibid.

32 Ibid.

33 Ibid.

34 Ibid.

35 Diary entry, February 14, 1919, C. M. Storey Journal.

36 Diary entry, February 15, 1919, C. M. Storey Journal.

37 Diary entry, February 15, 1919, C. M. Storey Journal. 
38 Diary entry, February 19, 1919, C. M. Storey Journal.

39 Roosevelt, A History of a Few Weeks, (unpublished manuscript).

40 Diary entry, February 24, 1919, C. M. Storey Journal.

41 Diary entry, February 24, 1919, C. M. Storey Journal.

42 Diary entry, February 24, 1919, C. M. Storey Journal.

43 Roosevelt, A History of a Few Weeks, (unpublished manuscript).

44 Roosevelt, A History of a Few Weeks, (unpublished manuscript). 